\title{
EFEKTIFITAS KONSUMSI JUS NANAS TERHADAP PENURUNAN TINGGI FUNDUS UTERI PADA IBU NIFAS DI KOTA PEKALONGAN
}

\author{
Ida Baroroh ${ }^{1}$, Hilda Prajayanti ${ }^{2}$ \\ Idabaroroh17@gmail.com \\ Akademi Kebidanan Harapan Ibu Pekalongan \\ J1. Sriwijaya No. 7 Kota Pekalongan. \\ Telp 085102998866
}

\begin{abstract}
ABSTRAK
Masa nifas merupakan masa yang diawali sejak beberapa jam setelah plasenta lahir dan berakhir setelah 6 minggu setelah melahirkan. Perubahan fisiologis yang terjadi pada masa nifas yaitu pengerutan pada uterus yaitu suatu proses kemabalinya uterus ke kondisi semula atau sebelum hamil dengan cara uterus berkontraksi. Proses penurunan tinggi fundus uteri ini dimulai sejak plasenta lahir, apabila proses ini gagal maka disebut sub involusio, sehingga akan memicu terjadi perdarahan pada masa nifas tersebut. Selain pengobatan secara medis, saat ini telah berkembang teknik pengobatan dengan menggunakan tanaman obat. Salah satu tanaman herbal yang dipercaya untuk memperlancar proses penyembuhan atau pemulihan adalah buah nanas. Upaya nonfarmakalogis untuk meningkatkan kontraksi uterus pada ibu post partum adalah dengan mengkonsumsi buah nanas karena kandungan enzim bromelinnya. Bromelin adalah salah satu enzim proteolitik atau protease yang ditemukan pada btanaman nanas (Ananas Comosus (L.Merr)comosus) dan tidak dimiliki oleh buah lainnya. Kandungan bromelin dalam buah nanas paling banyak terdapat di batang dan buah, sedangkan di bagian lain hanya mengandung bromelin dalam jumlah sedikit. Tujuan Penelitian yaitu Mengetahui efektifitas konsumsi jus nanas terhadap penurunan tinggi fundus uteri pada ibu post partum primipara di Kota Pekalongan.Desain Penelian yang digunakan desain penelitian quasi experimental dengan rancangan yang digunakan adalah nonequivalent control group design. Pada penelitian ini menggunakan dua kelompok yaitu kelompok perlakuan dan kelompok kontrol. Kelompok perlakuan diberikan intervensi berupa pemberian jus nanas selama 7 hari yang dicatat pada lembar observasi pemberian jus nanas dan kelompok kontrol diberikan pendidikan kesehatan kebutuhan nutrisis ibu post partum.Hail penelitian diperoleh bahwa Nilai rata-rata penurunan TFU kelompok perlakuan pada kondisi awal mencapai $11,9 \mathrm{~cm}$ kemudian mengalami penurunan menjadi $2,5 \mathrm{~cm}$ pada hari ketujuh. Rata-rata penurunan TFU kelompok kontrol pada kondisi awal mencapai 14,4 cm kemudian mengalami penurunan menjadi 7,4 cm pada hari ketujuh. Grafik menunjukkan adanya efek dari perlakuan yaitu pemberian jus nanas terhadap penurunan tinggi fundus uteri.
\end{abstract}

Kata Kunci

: Nifas, Jus Nanas, Penurunan Tinggi Fundus Uteri

\section{Pendahuluan}

Berdasarkan Survey Demografi Kesehatan Indonesia (SDKI) terakhir tahun 2007 Angka Kematian Ibu (AKI) Indonesia sebesar 228 per 100.000 Kelahiran Hidup (KH), angka tersebut masih menempati urutan tertinggi di Asia. Tiga faktor utama penyebab tingginya AKI yaitu perdarahan pervaginam (28\%), hipertensi saat hamil atau pre eklamsi (24\%) dan infeksi (11\%). ${ }^{1}$ Diperkirakan bahwa $60 \%$ kematian ibu akibat kehamilan terjadi setelah persalinan dan $50 \%$ kematian ibu pada masa nifas terjadi dalam 24 jam pertama yang sebagian besar disebabkan karena perdarahan post partum. $^{2}$

Masa nifas merupakan masa yang diawali sejak beberapa jam setelah plasenta lahir dan berakhir setelah 6 minggu setelah melahirkan. 3 Subinvolusio adalah kemacetan atau kelambatan penurunan tinggi fundus uteri yang disertai pemanjangan periode pengeluaran lokhea atau perdarahan banyak dan tidak teratur. Uterus teraba lunak dan lebih besar dari pada normalnya. Perubahan fisiologis yang terjadi pada masa nifas yaitu pengerutan pada uterus yaitu suatu proses kemabalinya uterus ke kondisi semula 
atau sebelum hamil dengan cara uterus berkontraksi. Proses penurrunan tinggi fundus uteri ini dimulai sejak plasenta lahir, apabila proses ini gagal maka disebut sub involusio, sehingga akan memicu terjadi perdarahan pada masa nifas tersebut. Subinvolusio adalah kemacetan atau kelambatan penurunan tinggi fundus uteri yang disertai pemanjangan periode pengeluaran lokhea atau perdarahan banyak dan tidak teratur. Uterus teraba lunak dan lebih besar dari pada normalnya. ${ }^{4}$

Proses involusio merupakan landasan yang penting bagi bidan dalam melakukan pemantauan proses fisiologis kembalinya uterus ke kondisi saat tidak hamil. Hal ini karena setelah kosong, uterus tetap mempertahankan struktur maskularnya dan tampak seperti kosong. Rongga uterus ini tetap berpotensi untuk membesar lagi, meskipun saat ini mengalami penurunan ukuran secara nyata. Hal inilah yang mendasari kebutuhan untuk melakukan observasi tinggi fundus uteri. ${ }^{4}$

Subinvolusio uterus merupakan salah satu penyebab terjadinya perdarahan, berdasarkan penelitian yang dilakukan oleh Gita dan Saced tentang Pola Normal Involusio Uterus dengan metode Symphisis Fundus Distance (SFD) pada wanita primipara di rumah sakit Fatemieh, Hamedan, Iran didapatkan bahwa masih ditemukan wanita mengalami subinvolusio sebanyak 21 responden dari total 180 responden yang disebabkan kurangnya kontraksi uterus yang adekuat. Oleh karena itu perlu dilakukan upaya untuk mempercepat proses involusio uteri dengan meningkatkan kontraksi uterus.

Perawatan masa post partum bertujuan untuk memperlancar proses pemulihan, memperlancar proses involusio dengan tujuan mencegah terjadinya komplikasi masa nifas. selain pengobatan secara medis, saat ini telah berkembang teknik pengobatan dengan menggunakan tanaman obat. Salah satu tanaman herbal yang dipercaya untuk memperlancar proses penyembuhan atau pemulihan adalah buah nanas. ${ }^{5}$

Jus nanas memiliki efek yang nyata terhadap penurunan TFU. Kajian terhadap manfaat jus nanas berkaitan dengan kandungan enzim Bromelin. Enzim ini adalah enzim proteolitik eksogen golongan proteinase sistein yang banyak digunakan dalam industri sebagai pelunak daging (digunakan bersamaan dengan enzim papain dari tanaman pepaya). Seperti diketahui, tingkat keempukan daging sebagian besar disebabkan oleh degradasi jaringan ikat. Enzim bromelin menunjukkan aktivitas hidrolitik pada jaringan ikat terutama terhadap kolagen dibandingkan terhadap protein myofibrilar yang lain. Aktivitas kolagenase bromelin dengan menghidrolisis kolagen diduga melalui akumulasi hidroksiprolin. Kolagen yang terhidrolisis oleh enzim bromelin membuat uterus menjadi lunak. ${ }^{6}$

$\begin{array}{rrr}\begin{array}{c}\text { Mugisha } \\ \text { mengemukakan }\end{array} & \begin{array}{c}\text { Origa } \\ \text { bahwa }\end{array} & \text { (2006) } \\ \text { nanas }\end{array}$ mengandung enzim bromealin yang dapat menstimulasi produksi prostaglandin yang memiliki efek merangsang kontraksi uterus. Muzaamman (2009) juga mengemukakan bahwa nanas juga mengandung serotonin yang merangsang terjadinya kontraksi uterus pada marmot betina yang hamil.

Upaya nonfarmakalogis untuk meningkatkan kontraksi uterus pada ibu post partum adalah dengan mengkonsumsi buah nanas karena kandungan enzim bromelinnya. Bromelin adalah salah satu enzim proteolitik atau protease yangditemukan pada btanaman nanas (Ananas Comosus (L.Merr)comosus) dan tidak dimiliki oleh buah lainnya. Kandungan bromelin dalam buah nanas paling banyak terdapat di batang dan buah, sedangkan di bagian lain hanya mengandung bromelin dalam jumlah sedikit.

\section{Metode Penelitian}

Penelitian ini menggunakan desain penelitian quasi experimental dengan rancangan yang digunakan adalah nonequivalent control group design. Pada penelitian ini menggunakan dua kelompok yaitu kelompok perlakuan dan kelompok kontrol. ${ }^{9}$

Kelompok perlakuan diberikan intervensi berupa pemberian jus nanas selama 7 hari yang dicatat pada lembar 
observasi pemberian jus nanas dan kelompok kontrol diberikan pendidikan kesehatan kebutuhan nutrisis ibu post partum.

Populasi dalam penelitian ini adalah 10 Ibu Nifas dengan kelompok perlakuan dan 10 Ibu Nifas dengan kelompok kontrol

Terhadap data yang terkumpul selanjutnya akan dilakukan analisis data menggunakan pengujian uji statistik Wilcoxon Signed Ranks Test dengan menggunakan SPSS versi 16

\section{Hasil dan Pembahasan}

a. Karakteristik Responden

Karakteristik responden adalah ciri khas yang melekat pada diri responden. Pada penelitian ini ciri khas yang ditampilkan adalah umur, pendidikan dan pekerjaan.

Tabel 4.1 Karakteristik Responden Berdasarkan Umur, Pendidikan, Pekerjaan

\begin{tabular}{lcc}
\hline Variabel & \multicolumn{2}{c}{ Mean \pm SD; Median; Min \pm Max } \\
\hline Umur (Tahun) & $\begin{array}{c}\text { Perlakuan } \\
(\mathbf{n = 1 0})\end{array}$ & $\begin{array}{c}\text { Kontrol } \\
(\mathbf{n = 1 0})\end{array}$ \\
\hline Pendidikan (\%) & $24,20 \pm 4,02 ;$ & $26,30 \pm 4,66 ; 25 ; 20 \pm 34$ \\
SMP & $1(10 \%)$ & \\
SMA & $6(60 \%)$ & $7(70 \%)$ \\
D III & $2(20 \%)$ & $3(30 \%)$ \\
S 1 & $1(10 \%)$ & $0(0 \%)$ \\
Pekerjaan (\%) & & \\
Tidak Bekerja & $6(60 \%)$ & $8(80 \%)$ \\
Buruh & $2(20 \%)$ & $0(0 \%)$ \\
Guru & $1(10 \%)$ & $0(0 \%)$ \\
Karyawan Swasta & $1(10 \%)$ & $1(10 \%)$ \\
Swasta & $0(0 \%)$ & $1(10 \%)$ \\
\hline
\end{tabular}

\begin{tabular}{|c|}
\hline $\begin{array}{l}\text { Berdasarkan tabel } \\
\text { Karakteristik } \\
\text { berdasarkan umur didapatkan } \\
\text { hasil padakelompok perlakuan } \\
\text { mean } 24,20 \text { tahun, median } 24,5 \\
\text { tahun, minimum } 18 \text { tahun dan } \\
\text { maksimum } 31 \text { tahun dengan } \\
\text { standar deviasi 4,02. Pada } \\
\text { kelompok kontrol didapatkan } \\
\text { hasil mean 26,30 tahun, median } \\
25 \text { tahun, minimum } 20 \text { tahun dan } \\
\text { maksimum } 34 \text { tahun dengan } \\
\text { standar deviasi } 4,66 \\
\text { Karakteristik resnonden }\end{array}$ \\
\hline
\end{tabular}

menunjukkan bahwa pada kelompok perlakuan terdapat 1 responden $(10 \%)$ berpendidikan SMP, 6 responden (60\%) berpendidikan SMA, 2 responden (20\%) berpendidikan DIII dan 1 responden $(10 \%)$ berpendidikan S1. Responden Kelompok control terdiri dari 7 responden $(70 \%)$ berpendidikan SMA dan responden dengan tingkat pendidikan DIII sebanyak 3 responden (30\%).

Karakteristik responden berdasarkan status pekerjaan menunjukkan bahwa pada kelompok perlakuan terdapat 6 responden $(60 \%)$ ibu yang tidak bekerja dan 4 responden (40\%) ibu yang bekerja sebagai buruh, guru dan karyawan swasta. Sedangkan pada kelompok kontrol terdapat 8 responden $(80 \%)$ Ibu yang tidak bekerja dan 2 responden (20\%) ibu yang bekerja sebagai karyawan swasta.

b. Hasil Analisa Bivariat

1) Hasil Uji Normalitas Data

Tabel 4.2 Hasil Uji Normalitas Data

\begin{tabular}{|c|c|c|c|c|}
\hline \multirow[b]{2}{*}{ Variabel } & \multirow[t]{2}{*}{ Kelompok } & \multicolumn{3}{|c|}{ Shapiro-Wilk } \\
\hline & & $\begin{array}{l}\text { Statisti } \\
\quad c\end{array}$ & $D f$ & Sig. \\
\hline & Perlakuan & ,953 & 10 & ,708 \\
\hline Umur & Kontrol & ,900 & 10 & ,220 \\
\hline & Perlakuan &, 841 & 10 &, 045 \\
\hline Pendidikan & Kontrol & ,594 & 10 & ,000 \\
\hline & Perlakuan & ,694 & 10 &, 001 \\
\hline Pekerjaan & Kontrol & ,532 & 10 &, 000 \\
\hline $\begin{array}{l}\text { Tinggi } \\
\text { Fundus Uteri }\end{array}$ & Perlakuan & ,888 & 10 & , 162 \\
\hline Pre test & Kontrol & ,922 & 10 & ,370 \\
\hline Tinggi & Perlakuan & ,920 & 10 & ,361 \\
\hline $\begin{array}{l}\text { Fundus } \\
\text { Uteri } \\
\text { Po } \\
\text { st test }\end{array}$ & Kontrol & ,961 & 10 & ,801 \\
\hline
\end{tabular}

Berdasarkan tabel 4.2, hasil uji normalitas data normal (sig > $0,05)$ yaitu variabel umur, tinggi fundus uteri pre test dan tinggi 
fundus uteri post test, sedangkan dengan distribusi data tidak normal yaitu variabel pendidikan dan pekerjaan

2) Efektifitas pemberian jus nanas terhadap tinggi fundus uteri

Hasil penelitian yang dilakukan di Wilayah Puskesmas Kota Pekalongan pada Bulan Febriari-Mei 2018 diperoleh data sebanyak 10 ibu nifas yang diberikan jus nanas sebagai kelompok perlakuan dan $10 \mathrm{ibu}$ nifas yang tidak diberikan jus nanas sebagai kelompok kontrol. Jus nanas diberikan selama 7 hari setiap hari diberikan jus nanas 1 kali sehari sebanyak 200 gram nanas. Setiap hari dilakukan pengukuran tinggi fundus uteri (TFU). Berikut akan disajikan data hasil penelitian tentang penurunan TFU pada ibu nifas.

Tabel 4.4 Penurunan TFU pada Tiap Kelompok Perlakuan (dalam $\mathrm{cm}$ )

\begin{tabular}{lccccccc}
\hline \multicolumn{10}{c}{ Hari Ke- } \\
Kelo & I & II & II & I & V & V & V \\
mpo & & & I & V & & I & II \\
k & & & & & & & \\
Perl & 1 & 1 & 9 & 7 & 5 & 4 & 2 \\
akua & 1, & 0, & &, &, &, &, \\
n & 9 & 7 & & 3 & 9 & 6 & 5 \\
Kont & 1 & 1 & 1 & 9 & 9 & 8 & 7 \\
rol & 4, & 3, & 2, &, &, &, &, \\
& 4 & 5 & 1 & 7 & 6 & 3 & 4 \\
\hline
\end{tabular}

Nilai rata-rata penurunan TFU kelompok perlakuan pada kondisi awal mencapai $11,9 \mathrm{~cm}$ kemudian mengalami penurunan menjadi 2,5 $\mathrm{cm}$ pada hari ketujuh. Rata-rata penurunan TFU kelompok kontrol pada kondisi awal mencapai 14,4 $\mathrm{cm}$ kemudian mengalami penurunan menjadi $7,4 \mathrm{~cm}$ pada hari ketujuh. Grafik menunjukkan adanya efek dari perlakuan yaitu pemberian jus nanas terhadap penurunan tinggi fundus uteri.

Analisis data untuk mengetahui adanya perbedaan penurunan tinggi fundus uteri antara kelompok perlakuan dan kelompok kontrol digunakan uji t independent.dari hasil perhitungan diperoleh hasil sebagai berikut:

Tabel 4.5 efektifitas pemberian jus nanas terhadap tinggi fundus uteri

\begin{tabular}{|c|c|c|c|c|}
\hline $\begin{array}{l}\text { Kelomp } \\
\text { ok }\end{array}$ & $\begin{array}{c}\text { Rat } \\
\text { a- } \\
\text { rata } \\
(\mathrm{cm} \\
\text { ) }\end{array}$ & $\begin{array}{c}\mathrm{t}_{\text {hitun }} \\
\mathrm{g}\end{array}$ & $\begin{array}{c}\mathrm{p} \\
\text { valu } \\
e\end{array}$ & sig \\
\hline $\begin{array}{l}\text { Perlaku } \\
\text { an }\end{array}$ & 9,4 & $\begin{array}{c}6,58 \\
9\end{array}$ & $\begin{array}{c}0,16 \\
6\end{array}$ & \\
\hline
\end{tabular}

Kontrol 7

Hasil analisis data untuk
uji homogenitas (perbedaan
varian) dengan lavene's test
didapatkan nilai p 0,166 (p >
0,05 ), maka dapat dikatakan
bahwa tidak ada perbedaan
varians pada data penurunan
tinggi fundus uteri pada ibu nifas
yang diberikan jus nanas dan
yang tidak diberikan jus nanas.
Hasil uji independentsample t test
diperoleh nilai thitung sebesar 6,589
(sig $>0,05$ ) yang artinya ada
perbedaan penurunan tinggi
fundus uteri antara ibu nifas yang
diberikan jus nanas dan yang
tidak diberikan jus nanas. Nilai
rata-rata penurunan tinggi fundus
uteri pada kelompok perlakuan
mencapai 9,4 cm lebih tinggi
daripada rata-rata penurunan
tinggi fundus uteri pada
kelompok kontrol yang hanya
mencapai 7 cm. hal ini
menunjukkan bahwa pemberian
jus nanas memiliki efektifitas
yang signifikan terhadap
penurunan tinggi fundus uteri
pada ibu nifas.

\section{Simpulan}

a. Karakteristik responden berdasarkan umur didapatkan hasil pada kelompok perlakuan mean 24,20 tahun, median 24,5 tahun, minimum 18 tahun dan maksimum 31 tahun dengan standar deviasi 4,02. Pada kelompok kontrol didapatkan hasil mean 26,30 tahun, median 25 tahun, minimum 20 tahun dan maksimum 
34 tahun dengan standar deviasi 4,66.

b. Karakteristik responden berdasarkan tingkat pendidikan menunjukkan bahwa pada kelompok perlakuan terdapat 1 responden (10\%) berpendidikan SMP, 6 responden $(60 \%)$ berpendidikan SMA, 2 responden $(20 \%)$ berpendidikan DIII dan 1 responden $(10 \%)$ berpendidikan S1. Responden Kelompok control terdiri dari 7 responden $\quad(70 \%)$ berpendidikan SMA dan responden dengan tingkat pendidikan DIII sebanyak 3 responden (30\%).

c. Karakteristik responden berdasarkan status pekerjaan menunjukkan bahwa pada kelompok perlakuan terdapat 6 responden $(60 \%)$ ibu yang tidak bekerja dan 4 responden (40\%) ibu yang bekerja sebagai buruh, guru dan karyawan swasta. Sedangkan pada kelompok kontrol terdapat 8 responden $(80 \%)$ Ibu yang tidak bekerja dan 2 responden (20\%) ibu yang bekerja sebagai karyawan swasta.

d. Nilai rata-rata penurunan TFU kelompok perlakuan pada kondisi awal mencapai $11,9 \mathrm{~cm}$ kemudian mengalami penurunan menjadi 2,5 $\mathrm{cm}$ pada hari ketujuh. Rata-rata penurunan TFU kelompok kontrol pada kondisi awal mencapai $14,4 \mathrm{~cm}$ kemudian mengalami penurunan menjadi $7,4 \mathrm{~cm}$ pada hariketujuh. Grafik menunjukkan adanya efek dari perlakuan yaitu pemberian jus nanas terhadap penurunan tinggi fundus uteri.

\section{Daftar Pustaka}

[1] Depkes RI 2007. Manajemen Laktasi. Jakarta: Depkes RI

[2] Saefudin, A B, 2000. Buku Acuan Nasional Pelayanan Kesehatan Maternal dan Neonatal. Yayasan Pustaka Sarwono Prawirohardjo. Jakarta
[3] Suherni, Widyasih, Rahmawati. 2009. Perawatan nifas normal. Yogyakarta: Fitramaya

[4] Varney, H. Jan M. Kriebs, Carolin. 2007. Buku Ajar Asuhan Kebidanan. Cetakan I, edisi 4, volume 1. Jakarta: EGC

[5] Rahayu R.D. 2013. Perbedaan Penurunan Tinggi Fundus Uteri Setelah Pemberian Jus Nanas Pada Ibu Post Partum di Kabupaten Klaten. Surakarta

[6] Winda H. 2017. Pengaruh Pemberian Jus Nanas Terhadap Penurunan Tinggi Fundus Uteri pada Ibu Post Partum Primipara . Kudus

[7] Mugisha \& Origa. 2006. Medical Plants Used to Induced Labor During Childbirth in Western Uganda. Journal of Ethnomedicine. Di akses dari http://sciencedirect.com pada 20 maret 2017

[8] Muzzaman. 2009. Pengaruh Pemberian Ekstrak Buah Nanas terhadap Kontraksi Uterus Marmut Betina. Jurnal Farmakologi Indonesia. Edisi 3. Di akses dari http://www.kalbe.co.id/files/cdk 1

5_Kebidanan.pdf pada 21 Maret 2017

[9] Notoatmodjo, S. 2010. Metodologi Penelitian Kesehatan. Jakarta: Rineka Cipta

[10] Sastroasmoro, Sudigdo dan Ismail, S. 2011. Dasar-Dasar Metodologi Penelitian Klinis Edisi ke-4. Jakarta: Sagung Seto

[11] Sudigdo, S. 2011. Dasar-dasar Metodologi Penelitian Klinis Edisi $\mathrm{Ke}-4$. Jakarta : Sagung Seto.

[12] Suharsimi. 2006. Prosedur Penelitian Suatu Pendekatan Praktik. Jakarta : Rineka Cipta.

[13] Sutimah,2004. Hubungan antara pengetahuan dan perilaku Ibu Bekerja dengan pemberian ASI Eksklusif dengan ibu menyusui bayi berumur 5-12 bulan bekerja di bagian konveksi Batik Margaria Yogyakarta, KTI. 
